\title{
The West African enigma: Systematics, evolution, and palaeobiogeography of cardiid bivalve Procardium
}

\author{
Jan Johan ter Poorten And Rafael La Perna \\ Acta Palaeontologica Polonica 62 (4), 2017: 729-757 doi:https://doi.org/10.4202/app.00363.2017
}

Procardium gen. nov. is proposed for a group of early Miocene to Recent large cardiids in the subfamily Cardiinae. The type species is Cardium indicum, the only living representative, previously assigned to the genus Cardium. It is a mainly West African species, with a very limited occurrence in the westernmost Mediterranean. Procardium gen. nov. and Cardium differ markedly with regard to shell characters and have distinct evolutionary and biogeographic histories. Six species, in the early Miocene to Pleistocene range, and one Recent species are assigned to the new genus: Procardium magne $i$ sp. nov., $P$. jansseni sp. nov., $P$. danubianum, $P$. kunstleri, $P$. avisanense, $P$. diluvianum, and $P$. indicum. During the Miocene, Procardium gen. nov. had a wide distribution in Europe, including the Proto-Mediterranean Sea, Western and Central Paratethys and NE Atlantic, with a maximum diversity during the Langhian and Serravallian. Its palaeobiogeographic history was strongly controlled by climate. During the Langhian stage, warm conditions allowed the genus to reach its highest latitude, ca. $54^{\circ} \mathrm{N}$, in the southern North Sea Basin. With cooling, its latitudinal range gradually retreated southward, becoming mainly Mediterranean in the Pliocene-Pleistocene, and West African at present.

Key words: Bivalvia, Cardiidae, systematics, Neogene, Quaternary, Africa, Europe.

Jan Johan ter Poorten [terpoorten@ chello.nl], Integrative Research Center, Field Museum of Natural History, Chicago, IL 60605, USA. Rafael La Perna [rafael.laperna@uniba.it], Dipartimento di Scienze della Terra e GeoAmbientali, Università di Bari, Via Orabona 4, 70125 Bari, Italy.

This is an open-access article distributed under the terms of the Creative Commons Attribution License (for details please see creativecommons.org), which permits unrestricted use, distribution, and reproduction in any medium, provided the original author and source are credited. 
FoF Full text $(2,573.9 \mathrm{kB})$ 